\title{
CONSIDERAÇÕES SOBRE A APLICAÇÃO DOS DIREITOS DO CONSUMIDOR AOS MEIOS DE COMUNICAÇÃO DE MASSA NO BRASIL
}

\section{CONSIDERATIONS ABOUT THE APPLICATION OF CONSUMERS RIGHTS TO MASS MEDIA IN BRAZIL}

\author{
EDUARDO ARIENTE \\ Doutor em Direito pela Universidade de São Paulo (USP). \\ Professor da Universidade Presbiteriana Mackenzie. São Paulo, SP, Brasil. \\ eduariente@gmail.com
}

\section{RESUMO}

0 artigo pretende debater sobre os deveres dos meios de comunicação de massa diante dos direitos dos consumidores. Aborda, também, a questão da responsabilidade civil da atividade de comunicação social. Salienta a importância da pluralidade, transparência e dos direitos de resposta como elementos indispensáveis para o respeito ao público. Ao final, descreve alguns dos direitos do consumidor diante da imprensa, bem como defende o papel das associacões de defesa dos consumidores para a melhoria da qualidade dos serviços de informação.

Palavras-chave: Direito do consumidor; Meios de comunicação de massa; Responsabilidade Civil.

\begin{abstract}
This paper aims to discuss the duties of the mass media in light of consumer rights. It also addresses the question of civil liability of the media activity. It stresses the importance of plurality, transparency and the right to response as indispensable elements to respect the public. Finally, it describes some of the consumer rights before the press and it sustains the role of the associations of consumers to improve the quality of information services.
\end{abstract}

Keywords: Consumer Rights; Mass media; Civil liability. 


\section{SUMÁRIO}

INTRODUÇÃO; 1 CONFIGURAÇÃO DA RELAÇÃO DE CONSUMO ENTRE AS EMPRESAS DE COMUNICAÇÃO E SEUS LEITORES/TELESPECTADORES/OUVINTES; 2 RESPONSABILIZAÇÃO CIVIL DOS MEIOS DE COMUNICAÇÃO DE MASSA: OBJETIVA E SOLIDÁRIA; 3 A VERDADE, A OBJETIVIDADE E A TRANSPARÊNCIA; 4 PLURALIDADE E DIREITO DE RESPOSTA; CONCLUSÃO; REFERÊNCIAS.

\section{INTRODUÇÃO}

O presente artigo tem por finalidade discutir a incidência e as implicações dos direitos dos consumidores nas atividades dos meios de comunicação de massa no Brasil. Esse conjunto de direitos, consolidados mundialmente a partir da década de 1970, e neste país, no período pós Constituição de 1988, estabeleceu novas exigências sociais sobre qualidade dos produtos e serviços, bem como padrões de condutas mais rigorosos aos fornecedores de diversos mercados.

A qualidade dos serviços de radiodifusão no Brasil parece não ter acompanhado algumas legítimas demandas sociais. Como se tentará demonstrar, os direitos do consumidor não tiveram o devido alcance e aplicabilidade nas atividades da comunicação social e na imprensa, comparado com aquele efetivado em outros tipos de serviços.

As poucas iniciativas de sucesso de reação do público diante dos excessos da mídia dizem respeito às ações coletivas movidas por legitimados públicos, bem como às vítimas diretamente atingidas por excesso de linguagem, dizeres levianos, preconceitos e atentados contra a dignidade humana. Talvez a falsa aparência de gratuidade das atividades dos serviços de radiodifusão cause certo ressentimento aos consumidores quanto à qualidade e ao respeito que seria devido aos direitos fundamentais.

As entidades públicas e privadas ligadas à defesa dos consumidores poderiam desempenhar um papel relevantíssimo em relação aos serviços de radiodifusão e de imprensa. 0 know-how adquirido durante tantos anos por essas instituições, em matéria de consumo, sobretudo em tutela coletiva, pode representar importante instrumento para a construção de uma mídia mais cidadã.

Não obstante as previsões constitucionais específicas sobre a liberdade de expressão (art. 50, IV) e comunicação social (art. 220 a 224), os direitos dos telespectadores consumidores - demandam maior estudo e aprofundamento (art. $\left.5^{\circ}, \mathrm{XXXII}, 170, \mathrm{~V}\right)$. 
CONSIDERAÇÕES SOBRE A APLICAÇÃO DOS DIREITOS DO CONSUMIDOR AOS MEIOS DE COMUNICAÇÃO DE MASSA NO BRASIL

Os serviços de informação e entretenimento dos meios de comunicação de massa possuem duas dimensões. As primeiras, sujeitas ao regime de concessão pública, referem-se à radiodifusão de sons e imagens. Um segundo grupo, das remanescentes, tais como portais na Internet, nas revistas e nos jornais impressos. 0 problema maior reside nos serviços concedidos à iniciativa privada. A regulamentação confusa e lacunosa não colabora com o controle social dos meios de comunicação. A atividade dos jornais e das revistas, seja impressa ou eletrônica, dispensa maiores regramentos estatais, pois não se referem a espaços públicos cuja finitude demandaria supervisão. Nas duas modalidades, porém, restam apenas as portas do Poder Judiciário para coibir eventuais abusos. ${ }^{1}$

O Executivo Federal, por motivos de falta de normatização adequada e também problemas de ordem política, que permitiram concessões realizadas de forma pouco republicana ${ }^{2}$, sempre foi bastante relutante em aprimorar essa modalidade de serviço público. ${ }^{3}$ A Lei de Concessões Públicas estranhamente não tratou da radiodifusão, como se esses serviços

\footnotetext{
${ }^{1}$ Vale ressaltar que existem comitês públicos sobre as atividades da mídia em diversos países do mundo. No Reino Unido, a OFCOM (Office of Communications) <http://www.ofcom.org.uk/about/what-is-ofcom/> zela pelos interesses dos consumidores em matéria de radiodifusão; na França o CSA (Conseil Supèrieur de L'Audiovisuel <http://www.csa.fr/> realiza atividade semelhante. No Brasil, o Conselho de Comunicação Social, previsto no texto de 1988, pouco saiu do papel e detém função apenas de aconselhamento. Acesso em: 28 jun. 2016.

2 BRASIL. Supremo Tribunal Federal. ADPF 429. Ação proposta pela Presidência da República em Novembro de 2016, requereu ao Supremo Tribunal Federal a declaração de inconstitucionalidade das decisões judiciais promovidas pelo Ministério Público Federal que têm impedido a outorga ou a renovação de concessões de rádio e TV a políticos. Disponível em: <http://www.stf.jus.br/portal/cms/verNoticiaDetalhe.asp?idConteudo=329213> Acesso em: 12 nov. 2016.

3 Afirmou Celso Antonio Bandeira de Mello: "Quando se trata de concessão ou permissão de rádio ou televisão, tal regra (art. 175 da C.F.) é inteiramente ignorada, seguindo-se muito disfarçadamente, a velha tradição de mero favoritismo. Como se sabe, é grande o número de congressistas que desfruta de tal benesse. Nesse setor reina - e não por acaso - autêntico descalabro. [...] acresce que, para completar o quadro confrangedor, uma única estação de televisão detém índices de audiência nacional esmagadores, ensejado pelo sistema de cadeias ou repetidoras de imagem - sistema que, aliás, constitui-se em manifesta burla ao espírito da legislação de telecomunicações. [...] o tratamento escandaloso que a Constituição dispensou ao assunto revela que inexiste coragem para enfrentar ou sequer incomodar forças tão poderosas - as maiores existentes no País. Veja-se: a disciplina da matéria foi estabelecida no art. 223 da Lei Magna. Ali se estabelece que a outorga e renovação da concessão, permissão ou autorização para radiodifusão sonora e de sons e imagens competem ao Poder Executivo, mas que o Congresso Nacional apreciará tais atos no mesmo prazo e condições conferidos aos projetos de lei de iniciativa do Presidente, para os quais este haja demandado urgência. Agora, pasme-se: para não ser renovada concessão ou permissão é necessária deliberação de $2 / 5$ (dois quintos) do Congresso Nacional e por votação nominal! Contudo, há mais, ainda: o cancelamento de concessões ou permissões antes de vencido o prazo (que é de 10 anos para emissoras de rádio e de 15 para as de televisão) só poderá ocorrer por decisão judicial, contrariando, assim, a regra geral que faculta ao concedente extinguir concessões ou permissões de serviço público!". (grifos do autor) MELLO, Celso Antonio Bandeira de. Curso de Direito Administrativo. 12. Ed. São Paulo: Malheiros, 2000. p. 602-603.
} 
CONSIDERAÇÕES SOBRE A APLICAÇÃO DOS DIREITOS DO CONSUMIDOR AOS MEIOS DE COMUNICAÇÃO DE MASSA NO BRASIL

fossem espécies híbridas no ordenamento brasileiro. ${ }^{4}$ Porém, forçosamente, essas atividades empresariais continuam submetidas aos princípios constitucionais específicos. ${ }^{5}$

Do ponto de vista legal, o que se tem de mais preciso a respeito desses serviços é o Código Brasileiro de Telecomunicações, editado durante o governo do Presidente João Goulart. ${ }^{6}$ Outro regramento jurídico retirado do ordenamento foi a antiga Lei de Imprensa (Lei 5.250/67). Como se sabe, por ocasião do julgamento da ADPF 130/DF, o Supremo Tribunal Federal entendeu que essa norma era incompatível com a Constituição Federal. ${ }^{7}$ Hoje em dia no Brasil inexistem disposições específicas sobre a imprensa em leis ordinárias. Há apenas os regramentos convencionais - o Código Civil, Penal, e acrescentamos - o do Consumidor. ${ }^{8} 0$ regramento apenas do Direito Civil para os abusos da imprensa, como tentaremos demostrar, é insuficiente.

Nesse contexto em que esses serviços concedidos não sofrem um controle social adequado, com certa frequência, a notícia acaba se assemelhando ao espetáculo, à degradação e à editorialização de matérias supostamente investigativas, ancoradas muito mais no sensacionalismo do que no interesse público. Isto sem contar a escassez de divergência ideológica que toma conta da grande mídia. Muitas vezes, os especialistas que comentam certos temas na imprensa apenas são escolhidos em razão de a opinião deles coincidir com a do veículo que a divulga. A depender da figura do acusado, a pauta pode ser de uma nota de rodapé ou edições inteiras por longos períodos.

Os programas de auditório, por sua vez, trazem ao público a sordidez, os elementos mais íntimos da vida privada, assim como atentados diários contra a dignidade dos mais carentes, mulheres e demais minorias. Tais acontecimentos, infelizmente, parecem fazer parte

\footnotetext{
${ }^{4}$ BRASIL. LEI 8987/95. Lei das Concessões e Permissões Públicas. Diário Oficial da República Federativa do Brasil, Brasília, DF. Art. 41. O disposto nesta Lei não se aplica à concessão, permissão e autorização para o serviço de radiodifusão sonora e de sons e imagens. Disponível em: <http://www.planalto.gov.br/ccivil_03/leis/L8987cons.htm> Acesso em: 07 set. 2016.

${ }^{5}$ BRASIL. Constituição Federal de 1988. Diário Oficial da União. Brasília, DF: 5 out. 1988. Art. 220 a 224. Ver ainda NUNES JUNIOR, Vidal Serrano. Direito e jornalismo. São Paulo: Verbatim, 2011.

6 BRASIL. Código Brasileiro de Telecomunicações.Diário Oficial da República Federativa do Brasil, Brasília, DF. Disponível em: <http://www.planalto.gov.br/ccivil_03/leis/L4117.htm> Acesso em: 07 set. 2016.

${ }^{7}$ De outra banda, Freitas Nobre acreditava que uma lei específica sobre a imprensa poderia ser favorável aos emissores e receptores. Ver mais detalhes em NOBRE, Freitas. Imprensa e Liberdade: Os princípios constitucionais e a nova legislação. São Paulo: Summus, 1987, p. 35, 93.

${ }^{8}$ BRASIL. Supremo Tribunal Federal. Acórdão que julgou inconstitucional a suspensão da programação televisiva em razão de descumprimento da classificação indicativa prevista no Estatuto da Criança e do Adolescente para proteger a liberdade de expressão. PTB e AGU. Rel. Dias Toffoli. ADI 2404, j. 30 ago. $2016 . \quad$ Disponível em: <http://www.stf.jus.br/portal/processo/verProcessoAndamento.asp?numero=2404\&classe=ADI\&torigem=A P\&recurso=0\&tipoJulgamento= $M>$ Acesso em: 31 ago. 2016.
} 
da paisagem televisiva de forma cotidiana. ${ }^{9}$ Os demais serviços jornalísticos, sobretudo o da mídia escrita, mesmo que não sejam tão agressivos na disputa por audiência, também acabam atacando reputações sem o devido fundamento, ocultam seus interesses econômicos e ideológicos. Mesmo oferecendo espaço nos painéis dos leitores e o direito de resposta, as vítimas dos excessos da imprensa podem restar maculadas em suas honras de forma duradoura.

Os meios de comunicação de massa, quaisquer que sejam eles, por vezes passam longe dos princípios constitucionais que deveriam nortear as suas atividades. Os consumidores desses serviços não precisariam ser tão maltratados, tampouco receber menor importância do que os demais serviços oferecidos no mercado, tal qual o bancário, securitário, telefonia móvel, companhias aéreas, internet domiciliar, entre outros.

Toda forma de liberdade tem que se harmonizar com algum tipo de limite. Todavia, em função de problemas estruturais, de regulamentação e de centralidade do modelo privado da imprensa, temos uma elevada concentração do poder dos meios de comunicação no Brasil. Esse afunilamento do poder de emissão das informações ao grande público pode colaborar com o maltrato aos dispositivos sobre transparência (art. $4^{\circ}$, caput), da liberdade de escolha (art. $6^{\circ}$, II), a efetiva prevenção e reparação de danos patrimoniais e morais, individuais, coletivos e difusos (art. 6, $\mathrm{VI}$ ); e garantia legal de qualidade e adequação (art. 23 e 24, todos do CDC).

A maior polêmica que há no tema em estudo reside na objeção que certa parte da doutrina e dos tribunais brasileiros tem de aceitar a responsabilidade objetiva nessa seara, em razão de possíveis prejuízos à liberdade de imprensa. Pretende-se demonstrar ao final que tal relutância não se sustenta, pois, ao fortalecer os direitos dos telespectadores/consumidores, as matérias investigativas, de interesse público e que respeitam os direitos dos destinatários das mensagens em nada serão prejudicadas.

Com efeito, o presente artigo pretende discorrer sobre o cabimento do Código de Defesa do Consumidor à atividade dos meios de comunicação de massa, mediante consulta a jornais, revistas, doutrina jurídica em direito do consumidor, autores especializados em comunicação social, legislação, jurisprudência do Superior Tribunal de Justiça e do Supremo Tribunal Federal.

\footnotetext{
${ }^{9}$ Ver a esse respeito o Documentário produzido pelo Channel Four chamado "The Greatest Show on Earth", que retrata a visão de uma repórter britânica sobre a televisão brasileira. Disponível em: <https://www.youtube.com/watch?v=A-fAcJMT3lw> Acesso em: 26 jun. 2016.
} 


\section{CONFIGURAÇÃO DA RELAÇÃO DE CONSUMO ENTRE EMPRESAS DE COMUNICAÇÃO E SEUS LEITORES/TELESPECTADORES/OUVINTES}

Os veículos de comunicação costumam sobreviver à custa de recursos de publicidade e, em alguns casos, também de assinaturas. Prestam, portanto, serviços com profissionalismo, habitualidade e mediante remuneração, ora de forma direta, ora indireta. Tem-se, assim, o preenchimento de todos os requisitos para, em princípio, configurarem fornecedores de acordo com o Código de Defesa do Consumidor. ${ }^{10}$

Uma primeira dificuldade surge quando estuda-se a natureza jurídica dos serviços públicos de radiodifusão sob concessão pública. É verdade que, num primeiro olhar, o regramento dos serviços públicos submetidos à disciplina consumerista ${ }^{11}$ parece ser direcionado apenas aos serviços públicos previstos na lei sobre concessões públicas (Lei n. 8.987/95). Entretanto, esse critério não pode ser único, tampouco deve ser interpretado isoladamente. Dada a especificidade desse mercado, acreditamos que o CDC é aplicável às relações entre as empresas de mídia e os telespectadores - consumidores.

Outra característica peculiar desse serviço trata da forma de remuneração. Os serviços públicos regidos pelo CDC, em princípio, têm contraprestação apenas de forma direta (uti singuli) e não de forma indireta (uti universi). ${ }^{12}$ Nesta situação sob análise, a remuneração do serviço seria, em princípio, indireta, pois as empresas de rádio e TV têm como principais receitas a publicidade proveniente de órgãos públicos e privados. Por conseguinte, os critérios convencionais para diferenciar o serviço regido pelo CDC ou não de acordo com a forma de pagamento nos parecem insuficientes.

Por motivos de isonomia, não haveria razão para tratar as empresas de comunicação exploradoras de serviços públicos de maneira diferenciada das demais empresas regidas pelo Código de Defesa do Consumidor remuneradas direta ou indiretamente. Elas obtêm lucro e

\footnotetext{
${ }^{10}$ MARQUES, Claudia Lima. Contratos no Código de Defesa do Consumidor. São Paulo: RT, 2011, p. 407. CALAIS-AULOY, Jean; STEINMETZ, Frank. Droit de la Consommation. Paris: Dalloz, 1996, p. 04 e ss. MIRAGEM, Bruno. Curso de Direito do Consumidor. São Paulo: RT, 2014, p. 143 ss.

11 BRASIL. Lei 8987/95. Lei das Concessões e Permissões Públicas. Art. 22. Os órgãos públicos, por si ou suas empresas, concessionárias, permissionárias ou sob qualquer outra forma de empreendimento, são obrigados a fornecer serviços adequados, eficientes, seguros e, quanto aos essenciais, contínuos. Diário Oficial da República Federativa do Brasil, Brasília, DF Disponível em: <http://www.planalto.gov.br/ccivil_03/leis/L8987cons.htm> Acesso em: 07 set. 2016.

12 MARQUES, Claudia Lima; BENJAM̄IN, Antonio Herman; MIRAGEM, Bruno. Comentários ao Código de Defesa do Consumidor. São Paulo: RT, 2013. p. 644 ss. Ver também MIRAGEM, Bruno. Op. cit. p. 180-190.
} 
exercem atividade que pode ser de risco. Assim como outras empresas da chamada "economia do conhecimento" têm como matéria-prima a informação.

No outro lado da relação jurídica, temos os telespectadores, ouvintes e internautas de portais noticiosos, sejam eles assinantes ou não, que apresentam vulnerabilidade e também configuram inegavelmente destinatários finais desses mesmos serviços.

As formas de vulnerabilidade ${ }^{13}$, de acordo com a doutrina especializada, seriam pelo menos de ordem informativa, econômica e jurídica. Informativa, pela natureza do serviço prestado, bem como sobre o modo de funcionamento interno dele, que costuma ser desconhecido dos consumidores. Ora por artimanhas para atrair audiência, pelo apelo desnecessário à violência, assim como a falta de diversidade de pontos de vista, conforme as preferências editoriais da empresa, o processo de construção da notícia ainda é deveras obscuro para o grande púbico.

A vulnerabilidade econômica se traduz na discrepância de forças no campo financeiro. Algumas empresas de comunicação integram conglomerados empresariais com operações em diversos outros segmentos da economia, como editorial, fonográfico, de provedor de conexão e de conteúdo, produtora de filmes, sites de internet, entre outros.

A Rede Globo, entre os anos de 2003 a 2014, recebeu de publicidade do governo federal mais de R\$ 6 Bilhões. ${ }^{14}$ A receita com os direitos de transmissão de futebol da mesma emissora, referente ao ano de 2015, chegou a R\$ 14 Bilhões. ${ }^{15}$ Segundo tabela do Jornal Folha de São Paulo, válida para o ano de 2014, uma publicidade feita em página inteira, em caderno nacional, varia de $R \$ 332.000,00$, nos dias de semana, a $R \$ 432.000,00$ aos domingos. ${ }^{16}$ Mesmo que os demais veículos de radiodifusão e imprensa não atinjam essa magnitude de valores, é certo que

${ }_{13}$ Sobre o princípio da vulnerabilidade, ver MIRAGEM, Bruno. Curso de Direito do Consumidor. São Paulo:
RT, 2014, p. 121 e SS., MARQUES, Claudia Lima; BENJAMIN, Antônio Herman; MIRAGEM, Bruno.
Comentários ao Código de Defesa do Consumidor. São Paulo: RT, 2013 .
${ }_{14}$ RODRIGUES, Fernando. TV Globo recebeu R\$ 6,2 bilhões de publicidade federal com PT no Planalto.
JORNAL FOLHA DE SÃO PAULO. Disponível em: <http://www1. folha.uol.com.br/poder/2015/06/1649933-
tv-globo-recebeu-r-62-bilhoes-de-publicidade-federal-com-pt-no-planalto.shtml> Segundo a mesma
matéria, “Já a Record teve R\$ 2 bi de verbas nos 12 anos de Lula e Dilma. De 2003 a 2014 , SBT recebeu RS
1,6 bi; Band ficou com RS 1 bi. UOL obteve dados inéditos e exclusivos sobre publicidade federal Globo
ainda lidera em verbas estatais, mas tem queda em anos recentes. Rede TV!, com menos de 1 ponto de
audiência, recebeu R\$ 408 mi nos anos petistas.". Acesso em: 21 jun. 2016 .
${ }_{15}$ MATTOS, Rodrigo. "Veja quanto dinheiro a Globo ganha com o Brasileiro", assinada por Rodrigo Mattos.
PORTAL UOL. Segundo essa mesma matéria, a receita dos direitos de transmissão do futebol no ano de
2014 chegam a 16 Bilhões de Reais, ao passo que as despesas ficariam em torno de apenas 2 Bilhões.
Disponível em: <http://rodrigomattos.blogosfera.uol.com.br/2016/03/07/veja-quanto-dinheiro-a-globo-
ganha-com-o-brasileiro/> Acesso em: 20 jun. 2016 . 16 JORNAL FOLHA DE SÃO PAULO. Tabela de preços. Ano 2014. Disponível em: <http://publicidade.folha.com.br/files/fsp-pt.pdf> Acesso em: 20 jun. 2016. 
existe uma discrepância significativa de poderio econômico dessas empresas em face dos respectivos públicos, que muitas vezes sequer possuem outras fontes de informação e entretenimento.

A última modalidade de vulnerabilidade que pode ser aventada sobre o tema em exame seria a jurídica. De um lado da relação, os veículos costumam possuir escritórios próprios, parceiros ou terceirizados, ao passo que a maioria do público consumidor costuma amargar longas filas de espera para atendimento nas Defensorias Públicas.

O serviço prestado pelas emissoras de radiodifusão possui sustentabilidade financeira em razão das assinaturas e publicidade. Estas costumam ser feitas nos intervalos dos programas, palcos dos programas de auditório, merchandising nas novelas, transmissão de eventos esportivos, por vezes pronunciando o nome da empresa que pagou pelo "naming rights" dos estádios e clubes.

Nos idos de 2006, uma reportagem do site "Fórum Nacional pela Democratização da Comunicação" (FNDC) divulgou uma matéria sobre a falsa gratuidade desses serviços televisivos. Considerando os investimentos publicitários efetuados no ano anterior e o número de aparelhos televisores nos domicílios brasileiros, pagávamos o equivalente a R\$ 200,00 anuais para assistir a esses programas. Com efeito, esses valores se traduzem na prática em custos mais elevados nos produtos, serviços e tarifas que temos que desembolsar. ${ }^{17}$

Rizzatto Nunes bem tratou do tema quando aduziu que, sob a ótica do direito do consumidor, a remuneração do serviço não se relaciona com o preço cobrado, mas ao repasse, direto ou indireto, dos custos ao destinatário final. ${ }^{18}$ Neste sentido, nem o cafezinho do restaurante oferecido como cortesia, tampouco o estacionamento sem cobrança na cancela do shopping center seria efetivamente grátis, haja vista o incremento dos preços. ${ }^{19}$

Quando se trata de portais, os serviços buscam atrair os olhares dos consumidores para banners, sites de terceiros, tratamentos de dados pessoais dos usuários e "paywall" para filtrar

\footnotetext{
17 MARINI, Ana Rita; GORGEN, James. Quanto você paga para ver TV gratuita? Disponível em: <http://fndc.org.br/noticias/quanto-voce-paga-para-ver-a-tv-gratuita-29529/>. Acesso em: 04 jul. 2016. Segundo consta desta mesma matéria, "Em 2005, a televisão aberta faturou R\$ 9,507 bilhões com publicidade, sua principal fonte de receita e que representa $59,5 \%$ de todo o bolo publicitário brasileiro. Como existem no País 46.733.120 domicílios com receptores de TV, cada morador desembolsou R\$ 203,44 ao longo do ano - ou R\$ 16,95 por mês - para ver os programas. [...]. A taxa invisível aumenta se forem computados nesse cálculo o valor gasto pelos anunciantes para produzir os comerciais de TV. De acordo com o projeto Inter-Meios, em 2005 foram R\$ 4,16 bilhões investidos na produção comercial de anúncios em todos os meios de comunicação".

${ }^{18}$ NUNES, Rizzatto. Curso de Direito do Consumidor. São Paulo: Saraiva, 2013, p. 151.

${ }^{19}$ NUNES, Rizzatto. Curso de Direito do Consumidor. São Paulo: Saraiva, 2013, p. 151.
} 
assinantes do serviço dos visitantes habituais. As mídias impressas costumam recorrer a anúncios, por vezes de páginas inteiras, classificados, brindes e promoções, assinaturas e vendas em bancas de jornal.

Em todos os casos mencionados, existe a figura do consumidor convencional ou padrão, que representam os assinantes e os telespectadores, e também os consumidores por equiparação, para as demais pessoas atingidas, ora por acidente de consumo, ora por práticas comerciais abusivas ou enganosas (Art. $2^{\circ}$, Par., 17 e 28 do CDC).

Alguns precedentes judiciais enxergam nos serviços de radiodifusão uma relação de consumo. Conforme assentou o Min. Ruy Rosado de Aguiar,

O relacionamento entre o canal de televisão e seu público caracteriza uma relação de consumo, na qual a emissora presta um serviço ao espectador e se beneficia com a audiência, em razão da qual aufere renda. Portanto, nessa atividade deve manter obediência aos princípios de moralidade e transparência, exigida de qualquer entidade que atua junto ao público. ${ }^{20}$

Mesmo raciocínio foi adotado pelo Min. Luis Felipe Salomão: “a retransmissora, tal qual a emissora, se enquadram ao conceito de fornecedor de serviços, nos moldes do disposto no artigo $3^{\circ}$, § $2^{\circ}$, do Código de Defesa do Consumidor." ${ }^{21}$ Os demais serviços jornalísticos, ainda que não sejam figuras frequentes na jurisprudência de índole consumerista, pelas mesmas razões de ordem lógica, a nosso ver, estariam igualmente abrangidos pelo CDC. ${ }^{22}$

\footnotetext{
${ }^{20}$ BRASIL. Superior Tribunal de Justiça. Acórdão que reconheceu a existência de prática abusiva por emissora de televisão. SBT x MP-SP. Rel. Min. Ruy Rosado de Aguiar. Resp. 436.135 - SP, j. 17 jun. 2003. Disponível <http://www.stj.jus.br/SCON/jurisprudencia/toc.jsp?processo=436135\&\&b=ACOR\&thesaurus=JURIDICO\&p =true $>$ Acesso em: 20 ago. 2016.

${ }^{21}$ BRASIL. Superior Tribunal de Justiça. Acórdão que reconheceu a existência de relação de consumo entre retransmissora de televisão e telespectadores. Rel. Min. Luis Felipe Salomão. JULIANO TODESCHINI DE ANDRADE E OUTRO v. SOCIEDADE RÁDIO EMISSORA PARANAENSE S/A Resp. 946.851-PR, j. 15 mai. 2012. Disponível em: <http: / / www.stj.jus.br/SCON/jurisprudencia/toc.jsp?processo=946851\&\&b=ACOR\&thesaurus=JURIDICO\&p =true > Acesso em: 20 ago. 2016.

${ }^{22} \mathrm{O}$ mesmo entendimento partilhou Luiz Manoel Gomes Júnior, ancorado nas lições de Nelson Nery. Segundo Gomes Junior, "os órgãos de imprensa são fornecedores, nos termos do art. $3 .^{\circ}$ do CDC (LGL\1990\40), com a conduta regulada por esse Diploma Legal”. GOMES JUNIOR, Luiz Manoel. O Direito Difuso à informação verdadeira. E sua proteção por meio das ações coletivas - A função social da informação. Revista de Direito Privado. Vol. 10/2002 p. 154 - 164.
} 


\section{RESPONSABILIZAÇÃO CIVIL DOS MEIOS DE COMUNICAÇÃO DE MASSA: OBJETIVA E SOLIDÁRIA}

Como se sabe, responsabilidade civil objetiva é aquela que dispensa a comprovação de culpa do agente causador do dano. Como visto em tópico anterior, considerando que a relação jurídica firmada entre os meios de comunicação e seus telespectadores é de consumo, restaria indagar se o caminho adequado da responsabilização civil desses órgãos seria a objetiva ou quiçá aquela ancorada na teoria civilista da culpa.

Sobre as facetas da responsabilização civil possivelmente incidentes sobre os meios de comunicação na Internet, Bruno Miragem destaca três dimensões: (1) a do provedor de conteúdo na internet por conteúdo próprio; (2) a do provedor de conteúdo na Internet por ato de terceiros; (3) portal que desenvolve atividade típica de imprensa. No primeiro caso, sobre o provedor de conteúdo na Internet, assinalou o mestre gaúcho:

as atividades habitualmente realizadas na Internet - em caráter profissional, no mais das vezes, pelo provedor de conteúdo - dão causa a risco de danos a terceiros. Neste sentido, correta seria a aplicação da cláusula geral de responsabilidade por risco (artigo 927, parágrafo único, do Código Civil), assinalando o caráter objetivo desta responsabilidade para efeito de afastar a demonstração de culpa do provedor de Internet. Este, contudo, não é o entendimento do legislador ou da jurisprudência brasileira. [... ${ }^{23}$

Especificamente sobre a incidência do Marco Civil da Internet às atividades potencialmente sujeitas ao CDC, Bruno Miragem acredita que a norma consumerista é aplicável ao provedor de profissional quando se tratar de conteúdo próprio. Numa segunda situação, se a atividade do portal for tipicamente de imprensa, para o citado autor, seria adotado o Código Civil. $^{24}$

Entretanto, numa terceira faceta, discorda o referido jurista sobre a responsabilização subsidiária dos provedores de conteúdo nos atos causados por terceiros na Internet prevista no artigo 19 do Marco Civil. ${ }^{25}$ Segundo a argumentação desenvolvida, essa disposição fragiliza

\footnotetext{
${ }^{23}$ MIRAGEM, Bruno. Curso de Direito do Consumidor. São Paulo: RT, 2014, p. 596.

${ }^{24}$ MIRAGEM, Bruno. Curso de Direito do Consumidor. São Paulo: RT, 2014, p. 596.

${ }^{25}$ BRASIL. Lei 12.965/14. Marco Civil da Internet. Art. 19. Com o intuito de assegurar a liberdade de expressão e impedir a censura, o provedor de aplicações de internet somente poderá ser responsabilizado civilmente por danos decorrentes de conteúdo gerado por terceiros se, após ordem judicial específica, não tomar as providências para, no âmbito e nos limites técnicos do seu serviço e dentro do prazo assinalado, tornar indisponível o conteúdo apontado como infringente, ressalvadas as disposições legais em contrário.
} 
CONSIDERAÇÕES SOBRE A APLICAÇÃO DOS DIREITOS DO CONSUMIDOR AOS MEIOS DE COMUNICAÇÃO DE MASSA NO BRASIL

EDUARDO ARIENTE

demasiadamente a defesa das possíveis vítimas. Ademais, prossegue a crítica que o citado artigo deixa de empregar a teoria do risco-proveito: da vantagem econômica da atividade devem decorrer os riscos inerentes a ela. ${ }^{26}$ Seja como for, nem o jornalista do portal, tampouco o publicitário pode ser considerado terceiro em razão de sua atividade profissional vinculada ao provedor. $^{27}$

Conforme os julgados mais expressivos do Superior Tribunal de Justiça em matéria de erros da imprensa, prevalece a incidência do Código Civil e a responsabilidade subjetiva. Em regra, veremos que o posicionamento majoritário da doutrina e da jurisprudência parece fazer crer fundamental o elemento culpa para que surja o dever de indenizar. Segundo julgado relatado pela Min. Nancy Andrighi, não se aplica a teoria da responsabilidade objetiva aos órgãos de imprensa, que apenas respondem por condutas dolosas ou culposas. ${ }^{28}$

Acredita-se, contudo, que se trata de inquestionável relação de consumo aquela firmada entre os meios de comunicação, bem como os órgãos de imprensa, e seus assinantes e telespectadores, sobretudo por conteúdo próprio, independentemente de ser jornalístico ou não. Em termos precisos, para a situação em exame, não vemos fundamento jurídico para afastar a sistemática da responsabilização objetiva e solidária trazida pela codificação consumerista. Responsabilização subjetiva pelas regras consumeristas aplica-se, como se sabe, apenas aos profissionais liberais. ${ }^{29}$ Profissionais da imprensa e da mídia, todavia, não justificariam essa caracterização, tampouco podem ser considerados terceiros.

Mesmo se empregarmos a Teoria do Diálogo das Fontes, o Código Civil seria aplicado de forma apenas supletiva, quando for necessário sanar eventuais lacunas que a situação não apresenta. Para Claudia Lima Marques, “[...] As normas do Código Civil de 2002 podem ser

Diário Oficial da República Federativa do Brasil, Brasília, DF. Disponível em: <http://www.planalto.gov.br/ccivil_03/_ato2011-2014/2014/lei//12965.htm> Acesso em: 01 set. 2016.

${ }^{26}$ MIRAGEM, Bruno. Curso de Direito do Consumidor. São Paulo: RT, 2014, p. 597.

${ }^{27}$ MIRAGEM, Bruno. Curso de Direito do Consumidor. São Paulo: RT, 2014, p. 598.

28 BRASIL. Superior Tribunal de Justiça. Resp. No 1.328.914 - DF. Rel. Min. Nancy Andrighi. AÇÃO DE COMPENSAÇÃO POR DANOS MORAIS. PUBLICAÇÕES EM BLOG DE JORNALISTA. CONTEÚDO OFENSIVO. RESPONSABILIDADE CIVIL. Renan Calheiros v. Ricardo Noblat. J. 11 mar. 2014. Disponível em: <http:/ / www.stj.jus.br/SCON/jurisprudencia/toc.jsp?processo=1328914\&\&b=ACOR\&thesaurus=JURIDICO\& $\mathrm{p}=$ true $>$ Acesso em: 08 set. 2016.

29 BRASIL. Código de Defesa do Consumidor. Art. 14. O fornecedor de serviços responde, independentemente da existência de culpa, pela reparação dos danos causados aos consumidores por defeitos relativos à prestação dos serviços, bem como por informações insuficientes ou inadequadas sobre sua fruição e riscos. $\$ 4^{\circ}$ A responsabilidade pessoal dos profissionais liberais será apurada mediante a verificação de culpa. Diário Oficial da República Federativa do Brasil, Brasília, DF. Acesso em: 08 set. 2016. 
aplicadas às relações de consumo como normas gerais, subsidiárias e no que couber, ou quando especifiquem sua aplicação ao caso ou contrato". ${ }^{30}$

Segundo a citada autora, as relações entre Código do Consumidor e o Código Civil podem ser de três dimensões distintas: (i) na aplicação simultânea das duas leis, uma lei pode servir de base conceitual para a outra (diálogo sistemático de coerência), quando o microssistema do CDC se aproveita de conceitos fixados na lei geral, tais quais as definições de nulidade, pessoa jurídica, prova, decadência e prescrição; (ii) na aplicação coordenada entre as duas leis, uma delas pode complementar a aplicação da outra, dependendo de seu campo de aplicação no caso concreto (diálogo sistemático de complementaridade e subsidiariedade em antinomias aparentes ou reais), por exemplo, quando a disciplina civilista for, no caso concreto, mais vantajosa do que a consumerista; (iii) o diálogo das influências recíprocas sistemáticas, como no caso de uma possível redefinição do campo de aplicação de uma lei, o que pode suceder na relação entre dois consumidores ou dois fornecedores entre si. ${ }^{31}$

Situar o Código Civil em primeiro plano nesta relação entre produtores e seus receptores representaria uma fragilidade do público diante das emissoras e empresas de mídia. Não estamos a tratar de relações entre iguais, em que um mínimo de paridade existe entre os contratantes. ${ }^{32}$ Pelo contrário, a discrepância de poder, influência política e magnitude econômica entre as partes fazem com que a atuação das regras e princípios do CDC seja mais relevante.

No entender de Claudia Lima Marques,

Em nosso caso, a opção da Constituição Federal de 1988 de tutela especial aos consumidores, considerados agentes econômicos mais vulneráveis no mercado

\footnotetext{
${ }^{30}$ MARQUES, Cláudia Lima. Superação das antinomias pelo diálogo das fontes - o modelo brasileiro de coexistência entre o código de defesa do consumidor e o código civil de 2002. Revista de Direito do Consumidor | vol. 51/2004 | p. 34 - 67 | Jul. - Set / 2004. Doutrinas Essenciais de Direito do Consumidor | vol. 1 | p. 679 - 718 | Abr. / 2011 | DTR\2004\798, p. 13.

31 MARQUES, Cláudia Lima. Superação das antinomias pelo diálogo das fontes - o modelo brasileiro de coexistência entre o código de defesa do consumidor e o código civil de 2002. Revista de Direito do Consumidor | vol. 51/2004 | p. 34 - 67 | Jul. - Set / 2004. Doutrinas Essenciais de Direito do Consumidor | vol. 1 | p. 679 - 718 | Abr. / 2011 | DTR\2004\798, p. 16.

32 Ainda segundo Claudia Lima Marques, "Quem, neste momento, for ingênuo e seguir as primeiras visões do Código Civil de 2002, repetindo os preceitos do direito civil "dos iguais" do século XIX ou do Código Civil de 1916, contribuirá para o fim do direito comercial e para um esvaziamento inconstitucional do direito do consumidor. Quem, ainda, for ingênuo e seguir os modelos do eruditamente colocados como definitivos de direito comparado, sem um distanciamento crítico e rigor científico, transformará o Código Civil em centro, não só do Direito Privado, mas do direito econômico, desconstruindo as conquistas de tratamento diferenciado do direito comercial e da sociedade de consumo de massas no mercado brasileiro." MARQUES, Claudia Lima. Op. cit. p. 02.
} 
globalizado, foi uma demonstração de como a ordem econômica de direção deveria preparar o Brasil para a economia e a sociedade do século XXI. Efetivamente, o direito do consumidor é direito fundamental, direito humano de nova geração, direito social e econômico positivado na Constituição Brasileira (art. 5. ${ }^{\circ}$, XXXII, CF/1988) $)^{33}$

Desta feita, em vez de afastar o CDC das atividades da mídia, deve-se prestigiá-lo, notadamente nos aspectos de responsabilização objetiva, solidária, de facilitação de inversão do ônus probatório e adoção da teoria menor da desconsideração da personalidade jurídica, que independe da comprovação de fraude ou má-fé do causador do dano se necessário para indenizar a vítima. Dada a proteção constitucional ao direito do consumidor, nenhuma norma ordinária poderia juridicamente subtrair a garantia legal de adequação desses serviços. ${ }^{34} \mathrm{~A}$ rigor, salvo no caso dos profissionais liberais, a análise do elemento culpa, nos ilícitos engendrados pela imprensa e demais fornecedores, seria elemento secundário.

Nesse sentido, tendo em vista a inafastável subjetividade da atividade de colheita, seleção dos temas, forma e ênfase da divulgação de informações, eventuais incorreções seriam defensáveis pelos emissores não por ausência de culpa, mas por ausência de defeito no serviço prestado. ${ }^{35}$

Claudio Luiz Bueno de Godoy, mesmo defendendo que, do ponto de vista civil, os danos causados pela imprensa sejam regidos pelo Código de 2002, acredita que a situação pode ser tratada como atividade de risco especial, vale dizer, independente da comprovação de culpa. Para tanto, o referido autor entende que convém ponderar se o dano foi injusto, aquele não merecido ou provocado pela vítima. ${ }^{36}$

Defeituosa não é a informação emitida pelos fornecedores profissionais que se desassemelha com a verdade e a objetividade. É aquela cujos propagadores sequer tentaram trilhar os caminhos minimamente éticos da atividade da imprensa, do interesse público republicano, mediante checagem, busca, colheita e comparação de diversas fontes. Não menos relevante é o atendimento aos princípios do contraditório e do pluralismo democrático.

\footnotetext{
${ }^{33}$ MARQUES, Cláudia Lima. Superação das antinomias pelo diálogo das fontes - o modelo brasileiro de coexistência entre o código de defesa do consumidor e o código civil de 2002. Revista de Direito do Consumidor | vol. 51/2004 | p. 34 - 67 | Jul. - Set / 2004. Doutrinas Essenciais de Direito do Consumidor | vol. 1 | p. 679 - 718 | Abr. / 2011 | DTR\2004\798, p. 09.

${ }^{34}$ Cf. Art. 22 a 25 do Código de Defesa do Consumidor.

35 Obviamente, isso não afasta a excludente de responsabilização civil de culpa exclusiva de terceiro, prevista no art. 14 do Código de Defesa do Consumidor: Art. 14 [...] \& $3^{\circ} 0$ fornecedor de serviços só não será responsabilizado quando provar: I - que, tendo prestado o serviço, o defeito inexiste; II - a culpa exclusiva do consumidor ou de terceiro.

${ }^{36}$ GODOY, Claudio Luiz Bueno de. Liberdade de Imprensa e os direitos da personalidade. São Paulo: Atlas, 2008, p. 105.
} 
Posicionar o problema desta forma permitiria tanto a proteção dos consumidores como também o funcionamento da imprensa e dos meios de comunicação de forma livre, sem coagir ou desestimular reportagens sérias, de caráter investigativo e de interesse público. A liberdade de imprensa e a diversidade dos veículos sempre devem ser prestigiadas como valor fundamental das sociedades livres.

Soa no mínimo exagerado cogitar que o receio da responsabilidade objetiva consumerista (ou mesmo a capitulação da atividade como de risco) poderia servir como censura ou instrumento para podar a liberdade de imprensa. ${ }^{37}$ Talvez essa crítica pudesse ser mais bem acolhida no contexto antecedente à Constituição de 1988. Depois dela e da edição do CDC, parece desconsiderar esses novos paradigmas de proteção e ressocialização que norteou o direito privado.

Aqueles deslizes que se têm hoje como piores exemplos de jornalismo continuariam a ser sancionados: o caso da Escola Base, as entrevistas do apresentador Gugu com falsos integrantes do PCC, os preconceitos contra mulheres e homossexuais, bem como casos teatralizados do antigo programa “Tardes Quentes” do apresentador João Kleber, que obrigou a REDE TV! a exibir o primeiro direito de resposta coletivo da televisão brasileira.

Outros casos provocaram dano à coletividade pelo fato de o serviço prestado não ser apenas defeituoso, mas também negligente na checagem das informações. Em algumas situações, os equívocos podem provocar danos a terceiros, ao passo que noutros, apenas embaraços para a própria emissora.

Na primeira situação, por falta de cautelas elementares de checagem, alguns órgãos de comunicação estamparam a foto de Wilson Bueno, jornalista assassinado no Paraná, por retrato de outra pessoa quase homônima, o professor aposentado de jornalismo da USP Wilson da Costa

\footnotetext{
${ }^{37}$ Nesta vertente mais extremada pelo conflito entre responsabilidade objetiva e liberdade de imprensa, Luiz Manoel Gomes Júnior e Ricardo Alves de Oliveira entendem que "A responsabilidade objetiva, que independente da prova da culpa do agente, porque decorre de um fato ou serviço, representa uma vitória da evolução da responsabilidade civil. É uma teoria que surgiu para corrigir injustiças que se pontuavam pela dificuldade da prova dos atos ilícitos, penalizando pessoas débeis e submissas a encargos de risco, como empregados de fábricas, passageiros e consumidores [...] 0 conteúdo intelectual e a pauta da redação dos editoriais não se submetem a esse regime, porque seria, caso adotada a responsabilidade objetiva, a pior das censuras ao direito de informar. Os jornais poderiam fechar suas oficinas se fossem obrigados a indenizar todos aqueles, que de alguma forma, são citados nas notícias publicadas e essa situação ad terrorem somente beneficiaria os interessados em silenciar os jornalistas, o que é um absurdo. Urge, pois, reprimir essa tendência de incluir os jornais na responsabilidade objetiva, porque são eles responsáveis pelos danos quando agirem com dolo ou culpa." A RESPONSABILIDADE CIVIL DOS ÓRGÃOS DE IMPRENSA E A TEORIA DO RISCO CRIADO (art. 927, parágrafo único, do CC/2002). Revista de Direito Privado | vol. 28/2006 | p. 156 - 171 | Out - Dez / 2006. Doutrinas Essenciais de Responsabilidade Civil | vol. 8 | p. 571 - 588 |. Out / 2011 | DTR\2006\817.
} 
Bueno. ${ }^{38}$ Este segundo, vítima apenas da imprensa, soube pela sua própria filha e um cunhado que alguns canais de TV haviam noticiado seu falecimento. Como é de se esperar, um pânico generalizado tomou conta de sua família até a comprovação de que a notícia era falsa. ${ }^{39}$

No ano de 2011, o Padre Júlio Lancelotti, da Pastoral dos moradores de Rua de São Paulo, foi acusado de forma leviana de ter praticado pedofilia contra dois menores que ficaram algum tempo sob os seus cuidados. Apenas tempos depois de ter sido tachado de criminoso pela imprensa, conseguiu provar ser vítima de extorsão. Nas palavras do sacerdote:

Eu esperei que a poeira baixasse. Mas nunca baixou. Eu fui linchado, apedrejado. 0 circo que fizeram na porta da minha casa, o desrespeito com minha mãe que faleceu há cinco meses. [...] colocaram uma fita adesiva em minha campainha para me deixar louco. E fazer com que eu saísse na rua como doido para ver o que acontecia. Fotografaram minhas contas d'água. Perseguiam as pessoas que iam até a minha casa. Houve até uma pressão nos prédios vizinhos para tentar deixar as câmeras entrar para me fotografar dentro da minha casa. [...] Eu tenho uma mágoa muito grande com a imprensa, porque a imprensa não usou de inteligência. Foi extremamente em busca de manchetes. Perguntei uma vez para um jornalista: "Se eles disserem que eu tenho um arsenal de armas em casa, você vai publicar?" Ele disse que sim e em grande manchete. Respondeu ainda: "Depois, se não for verdade, a gente vai dizer o que acontece". ${ }^{40}$

A falta de checagem também vitimou doadores de roupas de criança e mantimentos para a mulher conhecida por "Mega grávida", do Município de Taubaté, no interior de São Paulo. A falsa gestante de quadrigêmeos apareceu em diversos programas de televisão. Os consumidores das notícias, comovidos com a aparente situação de penúria econômica da família, não mediram esforços para ajudá-la. Uma emissora de TV, em programa de assistencialismo de sua grade, doou um enxoval a ela. ${ }^{41}$

38 NALDONI, Thais. TVs e site divulgam morte de escritor com foto de jornalista homônimo. REVISTA IMPRENSA. Edição de 02 jun. 2010. Disponível em: <http://portalimprensa.com.br/noticias/ultimas_noticias/33635/tvs+e+site+divulgam+morte+de+escritor+ com+foto+de+jornalista+homonimo> Acesso em: 24 jun. 2016.

${ }_{39}$ BUENO, Wilson da Costa. Digam para a Band News, TV Gazeta e UOL que eu não morri! Portal Imprensa. Disponível

em: <http://portalimprensa.com.br/noticias/wilson+da+costa+bueno/678/digam+para+a+band+news+tv+gazet a+e+uol+que+eu+nao+morri> Edição de 07 jun. 2010. Acesso em: 24 jun. 2016.

${ }^{40}$ GUIMARAES, Arthur. "Fui linchado, apedrejado", diz padre Júlio Lancellotti sobre acusação de pedofilia. Portal UOL. <http://noticias.uol.com.br/cotidiano/ultimas-noticias/2011/05/24/fui-linchado-apedrejadodiz-padre-julio-lancellotti-sobre-acusacao-de-pedofilia.html> Edição de 24 mai. 2011. TRINDADE, Eliane. A Igreja sempre me apoiou, diz padre Júlio Lancellotti; JORNAL FOLHA DE SÂO PAULO. Edição de 25 mai. 2011. Disponível em: <http://www1.folha.uol.com.br/cotidiano/920793-a-igreja-sempre-me-apoiou-dizpadre-julio-lancellotti.shtml> Acesso em: 24 jun. 2016.

41 JORNAL O ESTADO DE SÂO PAULO. Com barriga de silicone, falsa grávida teria enganado até mesmo o marido em Taubaté (SP). Disponível em: <http://noticias.uol.com.br/ultimas-noticias/agenciaestado/2012/01/20/mulher-assume-nao-estar-gravida-de-quadrigemeos.htm> Acesso em: 20 jul. 2016. Ver 
CONSIDERAÇÕES SOBRE A APLICAÇÃO DOS DIREITOS DO CONSUMIDOR AOS MEIOS DE COMUNICAÇÃO DE MASSA NO BRASIL

Os enganos grosseiros não são feitos apenas por jornais ou profissionais brasileiros. 0 técnico de futebol Joel Santana, também por equívoco, teve sua imagem associada com delitos pela prestigiada Revista Time. Ele foi confundido com o marqueteiro João Santana, investigado na operação "Lava-Jato". ${ }^{42}$

O Jornal New York Times acreditou, por muito tempo, em informações oficiais da Casa Branca, sobre a existência de armas de destruição em posse de Saddam Hussein. A falta de investigação por parte da grande imprensa endossou o coro por uma segunda guerra norteamericana no Iraque. 0 então presidente George W. Bush ficou mais confortável em iniciar mais uma insanidade militar em razão de a decisão ter apoio de $72 \%$ dos norte-americanos. ${ }^{43}$

Em outras situações, não há exatamente dano aos consumidores. Revelam mais despreparo e embaraço para os próprios profissionais e veículos. O conhecido jornalista Mario Sergio Conti, numa viagem aérea de Rio de Janeiro a São Paulo, antes da Copa do Mundo de 2014, pensou ter tirado a sorte grande ao sentar próximo do então técnico da Seleção. Todavia, somente depois de publicar um suposto furo, nos Jornais O Globo, Folha e portal UOL, descobriu ter entrevistado Vladimir Palomo, sósia de Felipão. O jornalista obteve a declaração de que "Se tivéssemos três como ele (Neymar), a Copa seria uma tranquilidade". ${ }^{44}$

A revista Veja, certa feita, reproduziu, sem conferir adequadamente, informação divulgada pela revista New Scientist. Segundo o periódico, cientistas alemães estariam pesquisando a fusão de células de bovinos com tomateiros. 0 fruto desta árvore, que facilitaria

também o equívoco do Jornal Folha de São Paulo: LUCHETE, Felipe. 'Megagrávida' de Taubaté (SP) leva 4 Marias na barriga. Disponível em: <http://www1.folha.uol.com.br/cotidiano/2012/01/1031237megagravida-de-taubate-sp-leva-4-marias-na-barriga.shtml e da TV Rede Record <http://entretenimento.r7.com/hoje-em-dia/videos/gravida-de-quadrigemeas-se-emociona-comsurpresa-do-hoje-em-dia-20102015> Acesso em: 20 jul. 2016.

42 Portal F5. Disponível em: <http://f5.folha.uol.com.br/voceviu/2016/03/10000886-revista-time-trocajoao-santana-pelo-tecnico-joel-santana-em-reportagem-sobre-corrupcao-no-brasil.shtml> Edição de 24/03/2016. Acesso em: 20 jul. 2016.

${ }^{43}$ BROOKS, David. Learning From Mistakes. Jornal New York Times. Edição de 19/05/2014. Disponível em: <http://www.nytimes.com/2015/05/19/opinion/david-brooks-learning-from-mistakes.html?_r=0> Acesso em: 27 jun. 2016. Ver também KOZLOWSKA, Hanna. Who Was Right About W.M.D.s in Iraq? Jornal New York Times. Edição de 17 out. 2014. Disponível em: <http://op-talk.blogs.nytimes.com/2014/10/17/whowas-right-about-w-m-d-s-in-iraq/> Acesso em: 20 jul. 2016.

${ }^{44}$ NALDONI, Thais. Colunista de "Folha" e "O Globo" entrevista "falso" Felipão e gera "Erramos" em cascata. PORTAL IMPRENSA. Edição de 19 jun. 2014. Disponível em: <http://www.portalimprensa.com.br/noticias/ultimas_noticias/66418/colunista+de+folha+e+o+globo+entr evista+falso+felipao+e+gera+erramos+em+cascata> Acesso em: 20 jul. 2016 
em muito a vida das pessoas, seria um filé ao molho de tomate, o "Boimate". A matéria original, por óbvio, era falsa, em homenagem ao dia internacional da mentira. ${ }^{45}$

Por fim, não pode-se deixar de citar o documentário “O Abraço Corporativo”, produzido no Brasil em 2010, que mostra a superficialidade da imprensa brasileira. A trama mostra o protagonista Ari Itnem (mentira escrita ao contrário), falso consultor de RH, que ganhou fama na grande mídia (Folha de São Paulo e Rádio CBN) por falta de verificação das informações. 0 personagem foi divulgado como guru inovador de autoajuda empresarial pela falsa teoria do “Abraço Corporativo". ${ }^{46}$

Com efeito, inexiste incompatibilidade entre a legislação de proteção ao consumidor e a atividade da imprensa. Apenas o sensacionalismo e reportagens apressadas e malfeitas poderiam estar mais sujeitas a demandas judiciais pelas possíveis vítimas e entidades de proteção ao consumidor. Embora possa parecer muito fluido ou subjetivo falar de qualidade e adequação em matéria de mídia e imprensa, vê-se que há sim critérios mínimos, consensualmente aceitos, de qualidade, acatados pelos profissionais da imprensa, sindicatos, academia e público.

\section{A VERDADE, A OBJETIVIDADE E A TRANSPARÊNCIA}

Fábio Konder Comparato adverte que nas duas acepções etimológicas da palavra informação, há tanto uma vertente que designa a simples transmissão de fatos ou ideias, como uma segunda, que trata de formação ou modelagem de opiniões. Informação, destarte, é clara manifestação de poder. ${ }^{47}$

Pode parecer correto afirmar que o dever jornalístico se cumpre na medida em que traz reportagens precisas, verdadeiras e objetivas ao seu público. Mesmo referências do nosso direito constitucional acreditam que a liberdade de informação somente se justifica na medida em que ela for transmitida de forma correta e imparcial ${ }^{48}$. Objetividade jornalística é o discurso

\footnotetext{
${ }^{45}$ REVISTA ELETRONICA MIGALHAS. Dia da mentira: Relembre a brincadeira de $1^{\circ}$ de abril do "boimate" Edição de 01 abr. 2013. Disponível em: <http://www.migalhas.com.br/Quentes/17,MI175290,101048Dia+da+mentira+Relembre+a+brincadeira+de+1+de+abril+do+boimate> Acesso em: 24 jun. 2016.

46 O documentário “Abraço Corporativo" pode ser visto gratuitamente e na íntegra no site: $<$ https://vimeo.com/73639203> Acesso em: 24 jun. 2016.

${ }^{47}$ COMPARATO, Fábio Konder. Para Viver a Democracia. São Paulo: Brasiliense, 1989, p. 137-138.

${ }^{48}$ Ver, por todos, SILVA, José Afonso da. Curso de Direito Constitucional Positivo. São Paulo: Malheiros, 2001, p. 250. Também foram contundentes neste sentido a somatória de referências à "verdade" factual na ADPF 130. Algumas até acompanhadas de trechos bíblicos. Disponível em:
} 
empregado nos meios jornalísticos para conferir (ou aparentar) um mínimo de isenção e imparcialidade perante os leitores. 0 argumento é corriqueiro e deveras sedutor. ${ }^{49}$

Todavia, equiparar a prática jornalística ao descortinamento da verdade mediante critérios de objetividade parece-nos um tanto romântico e fundado mais na metafísica do que na realidade da imprensa brasileira. O Superior Tribunal de Justiça, em alguns casos que pesquisamos, parece trabalhar bem com a questão. Confira-se, a esse respeito, a Ministra Nancy Andrighi:

0 veículo de comunicação exime-se de culpa quando busca fontes fidedignas, uando exerce atividade investigativa, ouve as diversas partes interessadas e afasta quaisquer dúvidas sérias quanto à veracidade do que divulgará [...] Ressalte -se que a diligência que se deve exigir da imprensa, de verificar a informação antes de divulgá-la, não pode chegar ao ponto de que notícias não possam ser veiculadas até que haja certeza plena e absoluta da sua veracidade. 0 processo de divulgação de informações satisfaz verdadeiro interesse público, devendo ser célere e eficaz, razão pela qual não se coaduna com rigorismos próprios de um procedimento judicial, no qual se exige cognição plena e exauriente acerca dos fatos analisados. ${ }^{50}$

Não destoa o entendimento do Min. Luis Felipe Salomão:

Se, por um lado, não se permite a leviandade por parte da imprensa e a publicação de informações absolutamente inverídicas que possam atingir a honra da pessoa, não é menos certo, por outro lado, que da atividade jornalística não são exigidas verdades absolutas, provadas previamente em sede de investigações no âmbito administrativo, policial ou judicial.

0 dever de veracidade ao qual estão vinculados os órgãos de imprensa não deve consubstanciar-se dogma absoluto, ou condição peremptoriamente necessária à liberdade de imprensa, mas um compromisso ético com a informação verossímil, o que pode, eventualmente, abarcar informações não totalmente precisas. ${ }^{51}$

<http://redir.stf.jus.br/paginadorpub/paginador.jsp?docTP=AC\&doclD=605411> p. 37. Acesso em: 01 set. 2016.

49 Tal posicionamento, vê-se, por exemplo, no artigo RESPONSABILIDADE CIVIL DOS MEIOS DE COMUNICAÇÃO, de lavra de Luis Gustavo Grandinetti Castanho de Carvalho, publicado na Revista de Direito do Consumidor | vol. 47/2003 | p. 153 - 162 | Jul. - Set / 2003. Doutrinas Essenciais de Responsabilidade Civil | vol. 8 | p. 559 - 570 | Out / 2011 | DTR 2003।826. "O conceito de liberdade de imprensa transforma-se em um verdadeiro direito difuso da sociedade em receber informação verdadeira [...] E o que é a liberdade de imprensa senão o direito difuso da sociedade em receber informação verídica, transparente e imparcial, captada com seriedade e divulgada com retidão?".

${ }^{50}$ BRASIL. Superior Tribunal de Justiça. Resp. 1.414.887 - DF Rel. Min. Nancy Andrighi. Acórdão que negou pedido de danos morais em razão da busca por informações fidedignas do jornalista. Valdemar Costa Neto v. Editora Abril. J. 19 nov. 2013. Disponível em: <https: / / ww2.stj.jus.br/processo/pesquisa/?src=1.1.3\&aplicacao=processos.ea\&tipoPesquisa=tipoPesquisa Generica\&num_registro=201303125191 > Acesso em: 15 jun. 2016.

${ }^{51}$ BRASIL. Superior Tribunal de Justiça Rel. Resp. 680.794 - PR. Min. Luis Felipe Salomão. Acórdão que negou pedido de danos morais em razão da busca por informações fidedignas do jornalista. Vlaudemir Rigonato v. Editora Diário da Manhã. J. 17 jun. 2010. Disponível em: 
Ademais, esse discurso da objetividade e da veracidade pode mascarar interesses econômicos e políticos a respeito dos quais os consumidores podem não perceber. Consultemos alguns especialistas em comunicação a esse respeito.

Carlos Eduardo Lins da Silva ${ }^{52}$ narra que os valores liberdade e objetividade foram incorporados à imprensa brasileira por influência do jornalismo norte-americano ao final da $2^{\mathrm{a}}$ Guerra Mundial. Tanto um quanto outro foram considerados valores positivos pelos leitores em diversas pesquisas de opinião pública. Contudo, num olhar mais atento, representam mais mistificações do que a realidade dos profissionais da imprensa. Primeiro, porque a liberdade de imprensa no capitalismo se traduz em liberdade de empresa; segundo, porque objetividade é um valor impossível, uma vez que estamos presos inexoravelmente às nossas óticas particulares, à educação e valores de cada um. ${ }^{53}$

Sobre a questão da objetividade, prossegue o citado autor:

Enquanto nos EUA a maioria dos jornalistas dos veículos diz acreditar na objetividade e tenta pratica-la na medida do possível (com textos desadjetivados, contidos, com vários lados de uma questão ouvidos em condições de relativa igualdade), no Brasil todos se dizem objetivos, mas quase ninguém é.

E conclui:

O jornal, na imaginação popular, tem um destino heroico a cumprir. Na ingênua abordagem popular do assunto, jornalismo não é negócio, mas uma cruzada de campeões permanentemente em guarda contra as iniquidades. [...] no Brasil, assumir a defesa da objetividade nos seus termos americanos soa ingênuo demais mesmo para quem se aproxima dela. ${ }^{54}$

Noutra obra de referência ${ }^{55}$, Lins da Silva defende que a mediação da televisão comercial se torna mais eficaz na proporção em que menos pessoas se deem conta do seu caráter ideológico. ${ }^{56}$ Para que essa aparência de neutralidade empresarial da informação funcione, os veículos de comunicação recorrem ao entretenimento e ao prestígio social dos

<http://www.stj.jus.br/SCON/jurisprudencia/toc.jsp?processo=+680794\&\&b=ACOR\&thesaurus=JURIDICO\& $p=$ true $>$ Acesso em: 15 jun. 2016.

52 SILVA, Carlos Eduardo Lins da. O Adiantado da Hora: A influência americana sobre o jornalismo brasileiro. São Paulo: Summus, 1991, p. 89 e ss.

${ }^{53}$ Ibidem. p. 89.

${ }^{54}$ Ibidem. p. 103

${ }^{55}$ SILVA, Carlos Eduardo Lins da. Muito Além do Jardim Botânico: um estudo sobre a audiência do Jornal Nacional da Globo entre os trabalhadores. São Paulo: Summus, 1985, p. 54.

${ }^{56}$ Ibidem. p. 57-58. 
emissores. ${ }^{57}$ Os processos de seleção, edição, escolha das fontes e montagem são ignorados pela maioria dos telespectadores. Isso não quer dizer que as pessoas, por mais humildes que sejam, acreditem cegamente em tudo o que é dito pela imprensa. Porém, faltam a esses segmentos sociais alguns elementos críticos, por exemplo, sobre as relações de poder entabuladas pelas emissoras, inclusive entre elas e o Estado. ${ }^{58}$

Ciro Marcondes Filho, professor titular de jornalismo da ECA-USP, aborda a questão de modo semelhante. Para ele, a atividade da imprensa é essencialmente ideológica, na medida em que mascara seus interesses privados, comerciais e de classe sob os jargões de "verdade" e "objetividade". ${ }^{59}$ A seleção dos fatos, a forma de abordagem deles e a espetacularização são ingredientes dessa transformação da notícia em mercadoria. Segundo o autor:

A possibilidade de possuir a verdade é falsa e tende ao discurso dogmático; a objetividade é impossível. Isso não significa que tudo seja igualmente subjetivo ou que todas as expressões jornalísticas da realidade mantenham a mesma distância do real: há apropriações mais ou menos próximas da 'verdade dos fatos'. Estar-se-ia mais próximo - sem, contudo, jamais chegar - da objetividade, na medida em que [...] busque-se a informação que evita e denúncia, sofismas, instrumentos de persuasão ocultos, afirmações injustificadamente peremptórias; que difunde outras interpretações diferentes das dos dominantes, a fim de mostrar o caráter parcial e hipotético das mesmas; que declara explicitamente o caráter questionável da própria escolha e da própria valoração. ${ }^{60}$

Poder-se-ia adicionar à crítica da objetividade duas conhecidas teorias sobre jornalismo: as teorias do agenda setting ${ }^{61}$ e do gate keeper. ${ }^{62}$ A primeira trata dos efeitos das informações propagadas pelos meios de comunicação e a recepção dessas mensagens pelos cidadãos. A conclusão de várias pesquisas sobre o tema indica que, embora seja de difícil aferição prática, existe certa influência entre a agenda proposta pela imprensa e a agenda da sociedade. ${ }^{63}$

\footnotetext{
${ }^{57}$ SILVA, Carlos Eduardo Lins da. Muito Além do Jardim Botânico: um estudo sobre a audiência do Jornal Nacional da Globo entre os trabalhadores. São Paulo: Summus, 1985, p. 58.

${ }^{58}$ Ibidem. p. 126.

${ }^{59}$ MARCONDES FILHO, Ciro Juvenal. O Capital da Notícia - jornalismo como produção social da segunda natureza. São Paulo: Atica, 1986, p. 11.

${ }^{60}$ Ibidem. p. 12-18.

${ }^{61}$ MAIA, Kênia Beatriz Ferreira; AGNEZ, Luciane Fassarella. 0 agenda-setting no Brasil: contradições entre o sucesso e os limites epistemológicos. Disponível em: <http://www.compos.org.br/seer/index.php/ecompos/article/viewFile/504/466>. Acesso em: 16 jun. 2016.

62 SHOEMAKER, Pamela J. et al. Os Leitores como Gatekeepers das Notícias On-line. Disponível em: <http://bjr.sbpjor.org.br/bjr/article/view/247>. Acesso em: 24 jun. 2016.

${ }^{63}$ MAIA, Kênia Beatriz Ferreira; AGNEZ, Luciane Fassarella. 0 agenda-setting no Brasil: contradições entre o sucesso e os limites epistemológicos. Disponível em: <http://www.compos.org.br/seer/index.php/ecompos/article/viewFile/504/466> Acesso em: 16 jun. 2016.
} 
A segunda questiona o fator objetividade na medida em que enfatiza o processo de filtragem dos eventos, segundo critérios editoriais dos veículos. Cuida-se de perquirir o motivo pelo qual certos eventos se tornam notícias e outros não, inclusive a partir das relações de poder envolvidas. ${ }^{64}$

Nessa conformidade, os deveres de transparência e boa-fé da imprensa se afirmam não com discursos que proclamem atingir "a" verdade, tampouco "a" objetividade. Mais do que isso, significa uma obrigação perante os consumidores/telespectadores, que justamente escancara essas limitações de natureza objetiva e subjetiva.

Exibir os valores e preferências políticas e ideológicas dos veículos seria uma maneira saudável de transmitir ao público uma posição clara sobre as questões mais polêmicas. Embora seja possível que muitos leitores e anunciantes insatisfeitos possam não mais acompanhar o veículo, trata-se de uma forma respeitosa para lidar com os consumidores remanescentes.

Jornais dos Estados Unidos, por exemplo, divulgam abertamente suas preferências eleitorais quanto aos ocupantes da Casa Branca. ${ }^{65}$ No Brasil, essas manifestações dos veículos não ocorrem de forma tão comum. No referendo sobre a comercialização de armas de fogo em 2005, recorda-se que o Jornal Folha de São Paulo propagou pelo “não" ${ }^{66}$, ao passo que a revista Veja, pelo "sim". 67

De qualquer forma, mesmo que essas políticas não sejam plenamente satisfatórias ao ponto de evidenciarem certas manipulações e matérias tendenciosas, já seria um bom começo. Atendimento adequado a esses postulados talvez somente seja obtido mediante uma razoável pluralidade de veículos e opiniões.

\footnotetext{
${ }^{64}$ Os estudos seminais sobre os impactos da imprensa na opinião pública foram escritos em 1922 por Walter Lippmann, na obra "Public Opinion”. A obra recebeu tradução para o português em 2008 da editora Vozes.

${ }^{65}$ O Jornal New York Times, nas eleições de 2012, apoiou de modo explícito Barack Obama para a Presidência daquele País. Agora, passou a recomendar voto na senadora Hillary Clinton. Editorial Board. Jornal New York Times. Editorial Hillary Clinton for the Democratic Nomination. Disponível em: <http://www.nytimes.com/2016/01/31/opinion/sunday/hillary-clinton-endorsement.html?_r=0> Acesso em: 10 jun. 2016.

66 JORNAL FOLHA DE SÂO PAULO. Editorial Não Às Armas. Disponível em: <http://www1.folha.uol.com.br/fsp/opiniao/fz1505200501.htm> Edição de 15 mai. 2005. Acesso em: 24 jun. 2016.

${ }^{67}$ REVISTA VEJA. A capa da revista, na edição de 05 de outubro de 2005 estampava os dizeres "7 motivos para votar não: a proibição vai desarmar a população e fortalecer o arsenal dos bandidos”. Disponível em: <http://veja.abril.com.br/noticia/brasil/a-arte-de-iludir> Acesso em: 24 jun. 2016.
} 


\section{PLURALIDADE E DIREITO DE RESPOSTA}

Falar verdadeiramente em democracia é forçosamente falar em pluralidade de ideias no espaço público e convívio com diferenças culturais, religiosas e políticas. Essas mesmas diferenças, num espaço verdadeiramente democrático, deveriam compor as paisagens profissionais, sociais e midiáticas. A comunicação hoje, para Comparato, “é o grande ponto de interseção da vida política, social e econômica da atualidade". ${ }^{68}$

A respeito do panorama midiático, há uma antiga demanda por aprimoramentos e democratização. A questão de fundo é que a grande maioria dos veículos de radiodifusão tem feição empresarial. Tal aspecto colide efetivamente com o princípio constitucional da complementaridade dos sistemas privado, público e estatal. ${ }^{69}$

A predominância da visão empresarial tende a transformar a notícia em mercadoria e entretenimento. ${ }^{70}$ Ademais, pode distorcer o debate público, segundo as preferências editoriais dos seus proprietários, que ocupam destacado protagonismo no debate de ideias. Indubitavelmente, a concentração midiática prejudica o princípio da liberdade de escolha. ${ }^{71}$

Busca-se, assim, um horizonte de multiplicidade de vozes que possam ocupar o debate público sobre os temas fundamentais para o progresso de nossa sociedade. Quanto mais democratizado for esse debate, maior será a riqueza de narrativas que surgirão. Ao revés, quanto mais monopolizado o espaço midiático, mais escassos e superficiais tendem a ser as controvérsias políticas e ideológicas no espaço público.

Convém mencionar a esse respeito, trecho do voto do Ministro Joaquim Barbosa quando da ADPF 130, que tratou sobre a liberdade de expressão a partir da antiga de Imprensa:

[...] não basta ter uma Imprensa inteiramente livre. Em primeiro lugar, é preciso que ela seja suficientemente diversa e plural, de modo a oferecer os mais variados canais de sociedade; em segundo lugar, é preciso que essa salutar e necessária diversidade da Imprensa seja plena a ponto de impedir que haja concentração. Situações como as existentes em algumas unidades da nossa Federação, em que grupos hegemônicos dominam quase inteiramente a paisagem audiovisual e o mercado público de ideias e informações, com fins políticos, não é nada positivo para a formação da vontade pública e para a consolidação dos

\footnotetext{
${ }^{68}$ COMPARATO, Fábio Konder. É possível democratizar a televisão? In: NOVAES, Adauto. Rede Imaginária. Televisão e Democracia. São Paulo: Cia das Letras, 1991, p. 301.

${ }^{69}$ Cf. Artigo 223 da Constituição Federal.

70 MARCONDES FILHO, Ciro Juvenal. O Capital da Notícia - jornalismo como produção social da segunda natureza. São Paulo: Atica, 1986.

${ }^{71}$ Conforme Art. $6^{\circ}$, II do CDC.
} 
princípios democráticos. Noutras palavras, a concentração de mídia é algo extremamente nocivo para a democracia. ${ }^{72}$

Outra forma de democratizar o debate público se dá pelo manejo do Direito de Resposta. Convém citar definição que Freitas Nobre imprimiu a esse instituto:

o direito de resposta não aparece como a preocupação da troca de mensagens, preocupação que caracteriza a nossa civilização, mas ainda, como a defesa de terceiros envolvidos neste emaranhado de publicações, emissões e recepções. [...] Esta legítima defesa pressupõe, também, a agressão moral injusta, isto é, que a notícia seja passível de uma retificação [...] que esta agressão moral seja pesada e não simplesmente um comentário ou uma crítica desapaixonada; que a pessoa atingida pela publicação ou emissão ou seu representante legal a única a exercer este direito; que a resposta seja proporcional à agressão [...] é a legítima defesa na ordem moral..$^{73}$

Já segundo Vidal Serrano, o direito de resposta serve como espécie de contracrítica jornalística, de abertura do contraditório entre o crítico e o criticado. Assim, mais do que simplesmente permitir resposta a uma crítica, abre margem para o diálogo. ${ }^{74}$

Mesmo diante das diversas críticas direcionadas à nova regulamentação do Direito de Resposta, prevista na Lei $13.188 / 15^{75}$, especialmente sobre o prazo de contestação dos veículos $^{76}$, acredita-se que essa ferramenta é importantíssima para o convívio democrático entre a imprensa e seu público. O Direito de Resposta, adicionado à proteção do consumidor, pode trazer inestimáveis contribuições para a relação dos destinatários finais da informação com os prestadores desses serviços.

Caso seja difícil no presente momento construirmos uma pluralidade de veículos com visões substancialmente divergentes sobre os acontecimentos (pluralidade externa), o direito de resposta e os espaços dos leitores com críticas e elogios aos veículos podem conferir, ao menos, uma diversidade ideológica maior neles mesmos (pluralidade interna).

\footnotetext{
72 BRASIL. SUPREMO TRIBUNAL FEDERAL. ADPF 130 - DF. Rel. Min. Carlos Ayres Britto. Acórdão que revogou a Lei de Imprensa por incompatibilidade com a Constituição Federal de 1988. Disponível em: <http://redir.stf.jus.br/paginadorpub/paginador.jsp?docTP=AC\&doclD=605411 > Acesso em: 24 jun. 2016. ${ }^{73}$ NOBRE, Freitas. Lei da Informação. São Paulo: Saraiva, 1968, p. 94-97.

${ }^{74}$ NUNES JUNIOR, Vidal Serrano. Direito e Jornalismo. São Paulo: Verbatim, 2011, p. 140 ss.

75 BRASIL. Lei $13.188 / 15$. Dispõe sobre o direito de resposta ou retificação do ofendido em matéria divulgada, publicada ou transmitida por veículo de comunicação social. In: Diário Oficial da República Federativa do Brasil, Brasília, DF. Disponível em: <http://www.planalto.gov.br/ccivil_03/_Ato20152018/2015/Lei/L13188.htm> Acesso em: 08 set. 2016.

${ }^{76}$ Ver matéria "Criticada por advogados, lei que regula direito de resposta é publicada" veiculada no site Consultor Jurídico assinada por ROVER, Tadeu, que ilustra bem o modo pelo qual muitos advogados e profissionais analisaram a lei do Direito de Resposta. Disponível em: <http://www.conjur.com.br/2015nov-12/criticada-advogados-lei-direito-resposta-publicada> Acesso em: 10 jul. 2016.
} 


\section{CONCLUSÃO}

Os direitos do consumidor não são inimigos da liberdade da imprensa e da informação. Pelo contrário, são formas de garantir padrões mais elevados de respeito ao público. A norma consumerista teve relevante papel na socialização do direito privado no contexto pós Constituição de 1988. O Código Civil de 2002 fornece menos instrumentos às vítimas do que o Código de Defesa do Consumidor para reparar eventuais excessos cometidos pelos meios de comunicação e a imprensa.

Os serviços de difusão de informações, nos diversos tipos de mídia, deveriam ser enquadrados como relações de consumo. Trata-se de relações jurídicas de mercado firmadas entre fornecedores e consumidores com forças desiguais, premissa fundamental para aplicarmos o Código do Consumidor e não o Código Civil em possíveis litígios. Configuraria, ademais, quebra do princípio da isonomia com os demais fornecedores sujeitos ao CDC, inclusive aqueles que têm como matéria-prima a informação, como é o caso da chamada "economia do conhecimento".

Estão presentes, pelo lado das empresas, o profissionalismo, a habitualidade, a onerosidade direta ou indireta, e do outro o público destinatário final e vulnerável. Necessária consequência desses elementos é o regramento normativo consumerista, que adota a responsabilização civil objetiva, solidária, a facilitação da inversão do ônus da prova contra os causadores de dano, a adoção da teoria menor da desconsideração da personalidade jurídica da empresa causadora do dano, a competência do domicílio da vítima para propor a ação civil, entre outros direitos. Responsabilizar objetivamente a imprensa e os meios de comunicação não representa forma indireta de censura ou de tentar calar a imprensa séria, mas de ajustar aqueles fornecedores que não se preocupam efetivamente com as cautelas mínimas do jornalismo e o respeito à dignidade humana.

Inserir a responsabilização objetiva aos prestadores de serviços de informação nos meios de comunicação e no jornalismo representa uma garantia do público quanto à qualidade dos serviços, sobretudo de respeito à dignidade humana, dever de transparência, presunção de inocência, abertura às diversidades ideológica, cultural e religiosa. Isso não quer dizer que os veículos deveriam indenizar eventuais vítimas por não serem “objetivos”, “imparciais” ou se distanciarem da "verdade" factual. Acredita-se que essa forma de crítica da imprensa se mostra inadequada e tange a metafísica. Diversos juristas acabam aceitando essas premissas, que 
parecem equivocadas. Pensa-se que os estudos de profissionais da comunicação social indicados no presente trabalho restaram mais esclarecedores sobre o papel da imprensa nas suas relações de poder.

Prefere-se crer que a imprensa e os meios de comunicação são defeituosos na medida em que sequer buscaram trilhar os caminhos recomendáveis de respeito à dignidade humana, checagem, transparência, investigações de interesse público, abertura ao contraditório na notícia e à diversidade ideológica.

Ademais, pensa-se ser recomendável reforçar a importância do direito de resposta como instrumento de amplitude democrática dos meios de comunicação. Mesmo considerando as críticas efetuadas à novel legislação, cuida-se de elemento essencial de proteção à cidadania, considerando a discrepância de forças entre possíveis acusadores (mídia) e acusados (cidadãos), bem como os fornecedores de informação e o seu público.

Não menos relevante é a participação das entidades de defesa do consumidor na temática dos serviços da mídia. A presença combativa e a experiência acumulada por esses órgãos, inclusive no campo da Tutela Coletiva, poderiam colaborar para construirmos meios de comunicação mais qualificados, transparentes e cidadãos.

\section{REFERÊNCIAS}

BRASIL. Lei 4.117/62. Código Brasileiro de Telecomunicações. Diário Oficial da República Federativa do Brasil, Brasília, DF: Senado Federal, 1988. Disponível em:

<http://www.planalto.gov.br/ccivil_03/leis/L4117.htm> Acesso em: 07 Set. 2016.

BRASIL. Lei 8.078/90. Código de Defesa do Consumidor. Diário Oficial da República Federativa do Brasil, Brasília, DF: Senado Federal, 1988. Disponível em:

<http://www.planalto.gov.br/ccivil_03/leis/L8078.htm> Acesso em: 07 Set. 2016.

BRASIL. Constituição Federal. Diário Oficial da República Federativa do Brasil, Brasília, DF: Senado Federal, 1988. Disponível em:

<http://www.planalto.gov.br/ccivil_03/Constituicao/Constituiçao.htm>. Acesso em: 07 Set. 2016.

BRASIL. Lei 10.406/02. Código Civil. Diário Oficial da República Federativa do Brasil, Brasília, DF: Senado Federal, 1988. Disponível em:

<http://www.planalto.gov.br/ccivil_03//leis/2002/L10406.htm> Acesso em: 07 Set. 2016.

BRASIL. Lei 8987/95. Lei das Concessões e Permissões Públicas. Diário Oficial da República

Federativa do Brasil, Brasília, DF: Senado Federal, 1988. Disponível em:

<http://www.planalto.gov.br/ccivil_03/leis/L8987cons.htm> Acesso em: 07 Set. 2016. 
BRASIL. Lei 12.965/15. Marco Civil da Internet. Diário Oficial da República Federativa do Brasil, Brasília, DF: Senado Federal. Disponível em:

<http://www.planalto.gov.br/ccivil_03/_ato2011-2014/2014/lei/l12965.htm> Acesso em: 08 set. 2016.

BRASIL. Lei 13.188/15. Lei sobre o Direito de Resposta. Diário Oficial da República Federativa do Brasil, Brasília, DF. Disponível em: <http://www.planalto.gov.br/ccivil_03/_Ato20152018/2015/Lei/L13188.htm> Acesso em: 08 set. 2016.

BRASIL. Superior Tribunal de Justiça. Acórdão que reconheceu a existência de prática abusiva por emissora de televisão. SBT x MP-SP. Rel. Min. Ruy Rosado de Aguiar. Resp. 436.135 - SP, j. 17 jun. 2003. Disponível em:

<http: / /www.stj.jus.br/SCON/jurisprudencia/toc.jsp?processo=436135\&\&b=ACOR\&thesaurus=JU RIDICO\&p=true> Acesso em: 08 set. 2016.

BRASIL. Superior Tribunal de Justiça. Acórdão que reconheceu a existência de relação de consumo entre retransmissora os telespectadores. Rel. Min. Luis Felipe Salomão. JULIANO TODESCHINI DE ANDRADE E OUTRO v. SOCIEDADE RÁDIO EMISSORA PARANAENSE S/A Resp. 946.851-PR, j. j. 15 mai.2012. Disponível em:

<http: / /www.stj.jus.br/SCON/jurisprudencia/toc.jsp?processo=946851\&\&b=ACOR\&thesaurus=JU RIDICO\&p=true>. Acesso em: 08 set. 2016.

BRASIL. Superior Tribunal de Justiça. Resp. 1.414.887 - DF Rel. Min. Nancy Andrighi. Acórdão que negou pedido de danos morais em razão da busca por informações fidedignas do jornalista. Valdemar Costa Neto v. Editora Abril. J. 19/11/2013 . Disponível em: <https: / /ww2.stj.jus.br/processo/pesquisa/?src=1.1.3\&aplicacao=processos.ea\&tipoPesquisa=tip oPesquisaGenerica\&num_registro=201303125191 > Acesso em: 15 jun. 2016.

BRASIL. Superior Tribunal de Justiça Rel. Resp. 680.794 - PR :Min. Luis Felipe Salomão. Acórdão que negou pedido de danos morais em razão da busca por informações fidedignas do jornalista. Vlaudemir Rigonato v. Editora Diário da Manhã. J. 17/06/2010. Disponível em: <http: / / www.stj.jus.br/SCON/jurisprudencia/toc.jsp?processo=+680794\&\&b=ACOR\&thesaurus=J URIDICO\&p=true> Acesso em: 15 jun. 2016.

BRASIL. SUPREMO TRIBUNAL FEDERAL. ADPF 130/ DF. Rel. Min. Carlos Ayres Britto. Acórdão que revogou a Lei de Imprensa por incompatibilidade com a Constituição Federal de 1988. Disponível em: <http://redir.stf.jus.br/paginadorpub/paginador.jsp?docTP=AC\&docID=605411> Acesso em: 24 jun. 2016.

BRASIL. Supremo Tribunal Federal. ADPF 429. Ação proposta pela Presidência da República em Novembro de 2016, requereu ao Supremo Tribunal Federal a declaração de inconstitucionalidade das decisões judiciais promovidas pelo Ministério Público Federal que têm impedido a outorga ou a renovação de concessões de rádio e TV a políticos. Disponível em: <http://www.stf.jus.br/portal/cms/verNoticiaDetalhe.asp?idConteudo=329213> Acesso em: 12 nov. 2016.

BRASIL. Supremo Tribunal Federal. Acórdão que julgou inconstitucional a suspensão da programação televisiva em razão de descumprimento da classificação indicativa prevista no Estatuto da Criança e do Adolescente para proteger a liberdade de expressão. PTB e AGU. 
Rel. Dias Toffoli. ADI 2404, j. 30 ago.2016. Disponível em:

<http://www.stf.jus.br/portal/processo/verProcessoAndamento.asp?numero=2404\&classe=ADI\& origem $=A P \&$ recurso=0\&tipoJulgamento=M> Acesso em: 31 ago. 2016.

BROOKS, David. Learning From Mistakes. Jornal New York Times. Edição de 19/05/2014. Disponível em: <http: //www.nytimes.com/2015/05/19/opinion/david-brooks-learning-frommistakes.html?_r=0> Acesso em: 27 jun. 2016.

BUENO, Wilson da Costa. Digam para a Band News, TV Gazeta e UOL que eu não morri!. Portal Imprensa. Disponível em:

<http://portalimprensa.com.br/noticias/wilson+da+costa+bueno/678/digam+para+a+band+news +tv+gazeta+e+uol+que+eu+nao+morri> Acesso em: 24 jun. 2016.

CALAIS-AULOY, Jean; STEINMETZ, Frank. Droit de la Consommation. Paris: Dalloz, 1996.

CARVALHO, Luis Gustavo Grandinetti Castanho de. Responsabilidade Civil dos Meios de Comunicação. Revista de Direito do Consumidor | vol. 47/2003 | p. 153 - 162 | Jul. - Set / 2003.

CHANNEL FOUR. Documentário sobre a televisão brasileira THE GREATEST SHOW ON EARTH. Disponível em: <https://www.youtube.com/watch?v=A-fAcJMT3lw> Acesso em: 26 jun. 2016.

COMPARATO, Fábio Konder. É possível democratizar a televisão? In NOVAES, Adauto (org.). Rede Imaginária: Televisão e Democracia. São Paulo: Cia das Letras, 1991.

COMPARATO, Fábio Konder. Para Viver a Democracia. São Paulo: Brasiliense, 1989.

GODOY, Claudio Luiz Bueno de. Liberdade de Imprensa e os direitos da personalidade. São Paulo: Atlas, 2008

GOMES JUNIOR, Luiz Manoel; OLIVEIRA, Ricardo Alves de Oliveira. O Direito Difuso à informação verdadeira e sua proteção por meio das ações coletivas - A função social da informação. Revista de Direito Privado | vol. 10/2002 | p. 154 - 164 | Abr. - Jun. / 2002.

GUIMARAES, Arthur. "Fui linchado, apedrejado", diz padre Júlio Lancellotti sobre acusação de pedofilia. Portal UOL. Disponível em: <http://noticias.uol.com.br/cotidiano/ultimasnoticias/2011/05/24/fui-linchado-apedrejado-diz-padre-julio-lancellotti-sobre-acusacao-depedofilia.htm> Edição de 24/05/2011. Acesso em: 26 jun. 2016.

KOZLOWSKA, Hanna. Who Was Right About W.M.D.s in Iraq? Jornal New York Times. Edição de 17/10/2014. Disponível em: <http://op-talk.blogs.nytimes.com/2014/10/17/who-was-rightabout-w-m-d-s-in-iraq/> Acesso em: 24 jun. 2016.

LIPPMANN, Walter. Opinião Pública. São Paulo: Vozes, 2008.

MAIA. Kênia Beatriz Ferreira Maia; AGNEZ, Luciane Fassarella. O agenda-setting no Brasil: contradições entre o sucesso e os limites epistemológicos. Revista da Associação Nacional dos Programas de Pós-Graduação em Comunicação | E-compós, Brasília, v.13, n.3, set./dez. 2010. 
Disponível em: <http://www.compos.org.br/seer/index.php/ecompos/article/viewFile/504/466 > Acesso em: 01 jul. 2016.

MARCONDES FILHO, Ciro Juvenal. O capital da notícia - jornalismo como produção social da segunda natureza. São Paulo: Atica, 1986.

MARINI, Ana Rita; GORGEN, James. Quanto você paga para ver TV gratuita? Disponível em: <http://fndc.org.br/noticias/quanto-voce-paga-para-ver-a-tv-gratuita-29529/> Acesso em: 04 jul. 2016;

MARQUES, Claudia Lima. Contratos no Código de Defesa do Consumidor. São Paulo: RT, 2011.

MARQUES, Claudia Lima. Superação das antinomias pelo diálogo das fontes - O modelo brasileiro de coexistência entre o Código de Defesa do Consumidor e o Código Civil de 2002. Revista de Direito do Consumidor | vol. 51/2004 | p. 34 - 67 | Jul. - Set / 2004.

MARQUES, Claudia Lima; BENJAMIN, Antonio Herman; MIRAGEM, Bruno. Comentários ao Código de Defesa do Consumidor. São Paulo: RT, 2013.

MATTOS, Rodrigo. "Veja quanto dinheiro a Globo ganha com o Brasileiro", assinada por Rodrigo Mattos. PORTAL UOL. Disponível em:

http: //rodrigomattos.blogosfera.uol.com.br/2016/03/07/veja-quanto-dinheiro-a-globo-ganhacom-o-brasileiro/ Acesso em: 20 jun. 2016.

MELLO. Celso Antonio Bandeira de. Curso de Direito Administrativo. 12. Ed. São Paulo: Malheiros, 2000.

NALDONI, Thais. Colunista de "Folha" e "O Globo" entrevista "falso" Felipão e gera "Erramos" em cascata. PORTAL IMPRENSA. Edição de 19/06/2014. Disponível em:

<http://www.portalimprensa.com.br/noticias/ultimas_noticias/66418/colunista+de+folha+e+o+ globo+entrevista+falso+felipao+e+gera+erramos+em+cascata> Acesso em: 24 jun. 2016.

NALDONI, Thais. TVs e site divulgam morte de escritor com foto de jornalista homônimo.

REVISTA IMPRENSA. Edição de 02/06/2010. Disponível em:

<http://portalimprensa.com.br/noticias/ultimas_noticias/33635/tvs+e+site+divulgam+morte+de +escritor+com+foto+de+jornalista+homonimo> Acesso em: 25 jun. 2016.

MIRAGEM, Bruno. Curso de Direito do Consumidor. São Paulo: RT, 2014.

NOBRE, Freitas. Lei da Informação. São Paulo: Saraiva, 1968.

NOBRE, Freitas. Imprensa e Liberdade: Os princípios constitucionais e a nova legislação. São Paulo: Summus, 1987.

NUNES, RIZZATTO. Curso de Direito do Consumidor. São Paulo: Saraiva, 2013.

NUNES JUNIOR, Vidal Serrano. Direito e jornalismo. São Paulo: Verbatim, 2011.

REINO UNIDO. Office of Communications. Disponível em:

<http://www.ofcom.org.uk/about/what-is-ofcom/> Acesso em: 01 set. 2016. 
REPUBLICA FRANCESA. Conseil Supèrieur de L'Audiovisuel. Disponível em:

<http: //www.csa.fr/> Acesso em: 01 set. 2016.

RODRIGUES, Fernando. TV Globo recebeu R\$ 6,2 bilhões de publicidade federal com PT no Planalto. JORNAL FOLHA DE SÃO PAULO. Disponível em:

<http://www1.folha.uol.com.br/poder/2015/06/1649933-tv-globo-recebeu-r-62-bilhoes-depublicidade-federal-com-pt-no-planalto.shtml> Acesso em: 01 set. 2016.

SHOEMAKER, Pamela J. et al. Os Leitores como Gatekeepers das Notícias On-line.BRAZILIAN JOURNALISM RESEARCH - Volume 6 - Número 1 - 2010 Disponível em:

http://bjr.sbpjor.org.br/bjr/article/view/247 Acesso em: 01 ago. 2016.

SILVA, Carlos Eduardo Lins da. O Adiantado da Hora: A influência americana sobre o jornalismo brasileiro. São Paulo: Summus, 1991.

SILVA, Carlos Eduardo Lins da. Muito Além do Jardim Botânico: um estudo sobre a audiência do Jornal Nacional da Globo entre os trabalhadores. São Paulo: Summus, 1985.

SILVA, José Afonso da. Curso de Direito Constitucional Positivo. São Paulo: Malheiros, 2001.

TRINDADE, Eliane. A Igreja sempre me apoiou, diz padre Júlio Lancellotti; JORNAL FOLHA DE SÂO PAULO. Edição de 25/05/2011. Disponível em:

<http://www1.folha.uol.com.br/cotidiano/920793-a-igreja-sempre-me-apoiou-diz-padre-juliolancellotti.shtml> Acesso em: 01 set. 2016.

Recebido em: 08/09/2016 / Revisões requeridas em: 07/11/2016 / Aprovado em: 16/11/2016 